DOI: https://doi.org/10.46630/gped.1.2019.04

\title{
КОМПАРАТИВНА АНАЛИЗА МЕТОДОЛОШКЕ ГРУПЕ ПРЕДМЕТА НА СТУДИЈСКИМ ПРОГРАМИМА ПЕДАГОГИЈЕ У НИШУ, ЗАГРЕБУ, ОСИЈЕКУ И РИЈЕЦИ
}

\author{
Јелена Максимовић ${ }^{2}$, Јелена Османовић \\ Универзитет у Нишу, Филозофски факултет, Департман за педагогију
}

Ancmpaкm: Циљ основних студија педагогије огледа се у постизању компетенција, способности и вештина за рад у васпитно-образовној делатности. Од студената педагогије се очекује да помоћу адекватних метода, техника и инструмената на будућем радном месту стално евалуирају и иновирају васпитно-образовни процес. Предмет истраживања представља компарација присутности методолошких предмета на Филозофском факултету у Нишу, Загребу, Осијеку и Ријеци. Задаци компаративног истраживања су: 1. Анализирати силабусе студијских програма педагогије; 2. Компарацијом утврдити сличности и разлике у изучавању методолошке групе предмета студијских програма педагогије поменута четири факултета. Резултати компаративног истраживања показују да су методолошки предмети заступљени кроз студије педагогије док је највећи број предмета заступљен је на Филозофском факултету Свеучилиштва у Загребу. Закључује се да студијски програми теже да будуће педагоге кроз студије педагогије оформе у практичаре и истраживаче.

Кључне речи: компаративни метод, методолошки предмети, студијски програми, силабуси

\section{Увод}

Високошколско образовање, какво је преовладавало готово у целој Европи и широм света, претходна два века је по свом идентитету било оријентисано на развој науке, из чега су произлазиле све друге идентификације или

\footnotetext{
${ }^{1}$ Рад је настао као резултат рада на пројекту број 183/1-16-8-01, под називом Унапређивағе и осавремеъавање основних академских студија педагогије, финансираном од стране Филозофског факултета у Нишу.

${ }^{2}$ jelena.maksimović@filfak.ni.ac.rs
} 
одговорности - личне, професионалне и друштвене. Критеријум разликовања универзитетског од свих других видова високошколског образовања и осталих нивоа образовања јесте институционализација јединства образовања (наставе) и научног истраживања (Bodroški-Sporisou, 2015). Заједничке вредности и заједничко друштво су основна идеја Болоњске декларације. На овим идејама се грана развој високог школства у Европи и земљама региона које подразумева аутономију универзитета како би се они брже прилагођавали променама и потребама науке и технолошког напретка.

Из тог разлога подвргли смо се компаративном истраживању студијског програма у Нишу и Филозофских факултета Свеучилиштва у Загребу, Осијеку и Ријеци. Основни задатак овог компаративног истраживања јесте да кроз прегледни рад, табеларно-демонстративну анализу силабуса постављених на сајтовима поменутих факултета сагледа заступљеност циљева и исхода студирања, а самим тим и заступљеност методолошких предмета као саставног дела институционализованог високошколског образовања.

\section{1. Методологија педагогије у контексту исхода универзитетског образовања}

Од изузетног значаја је да се универзитетском образовању приступи врло одговорно и припреми будуће педагоге за бројне захтеве струке (KopasVukašinović i Maksimović, 2010). Раније се много више пажње посвећивало стицању психолошких, педагошких и методичких знања, а данас све више на значају добија методолошка група предмета и познавање основа методологије педагогије. Методологија педагогије је специфична дисциплина која проучава методе, начине или путеве научог сазнавања на подручју васпитања и образовања. Помоћу методологије студенти се оспособљавају за пројектовање истраживања, стичу знања о методама, техникама и инструментима, начинима прикупљања и обраде података и промишљају шта могу постићи добијеним резултатима истраживања. О значају методологије педагогије говорили су многи аутори (Savićević, 1996; Mužić, 2004; Banđur i Potkonjak, 1999; Milas, 2005; Cohen i sar., 2007).

Како би стигли до сазнања који методолошки предмети се изучавају на Филозофском факултету у Нишу, Загребу, Осијеку и Ријеци, било је неопходно најпре проверити сличности односно разлике у студијским програмима, и које то методолошке компетенције могу стећи студенти током универзитетског образовања на четири различита факултета, а затим упоредити силабусе где су анализирани предмети који се изучавају.

За студенте педагогије Филозофског факултета у Нишу предвиђено је да исходима образовања разумеју, анализирају, примене и евалуирају најзначајнија сазнања и идеје у педагогији као науци, да познају законе и принципе васпитно-образовног процеса, подстичу, развијају и унапређују интеракцију међу учесницима васпитно-образовног процеса, показују сензибилности за 
етичке и интеркултуралне проблеме. Студенти бивају оспособљени за прецизно конципирање налаза својих и туђих истраживања и оспособљавају се за компетентно презентовање добијених резултата истраживања (Studijski program pedagogije Filozofskog fakulteta u Nišu) ${ }^{3}$.

Студије педагогије у Нишу имају три нивоа студија, чине их основне академске студије педагогије које трају четири године када студент стиче звање дипломираног педагога. Затим следи наредни ниво студија, а то су мастер студије педагогије када студент након завршених студија стиче звање мастер педагога. На крају, трећи ниво студирања јесу докторске студије педагогије када студент стиче звање доктора педагошких наука.

Са друге стране, исходи студија педагогије Филозофског факултета у Загребу постављени су темељније и обимније и тај податак не чуди с обзиром на њихову специфичну коцепцију студирања. Филозофски факултет Свеучилишта у Загребу студентима нуди основне (преддипломске) и дипломске једнопредметне и двопредментне студије педагогије. Једнопредметне студије педагогије усмерене су на студирање само педагошке науке, док двопредметние студије студентима пружају могућности да студије педагогије комбинују са још једним студијским програмом. За разлику од концепције основних студија педагогије на Филозофском факултету у Нишу које трају 4 године (8 семестра - 240 ЕСПБ) након чега студенти стичу звање дипломирани педагог, на Филозофском факултету Свеучилишта у Загребу основне студије педагогије трају 3 године (6 семестра - 180 ЕЦТС бодова) након чега студенти стичу звање - свеучилишни првоступник/ца педагогије. За разлику од Филозофског факултета у Нишу, Филозофски факултет Свеучилишта у Загребу студентима нуди далеко шири дијапазон педагошких дисциплина за изучавање које се могу сврстати у категорију обавезних или изборних предмета, а што свакако детерминише и разлике у исходима учења ова два факултета.

Стога, издвајају се као поједини циљеви и исходи студија педагогије: Анализирати, расправити и критички вредновати образовне политике; анализирати педагошке теоријске дискурсе и установити сличности и разлике међу њима; Из педагошке перспективе критички анализирати и вредновати концепте и теорије сродних наука који се односе на васпитање и образовање; Издвојити и по потреби дизајнирати програм васпитања и образовања у складу с индивидуалним могућностима и потребама ученика; изабрати, прилагодити и применити педагошке моделе васпитања и образовања у виртуалном окружењу; Демонстрирати знања, вештине и способности потребне за наставак студија на дипломском нивоу; издвојити основне поступке обраде података у педагошким истраживањима, анализирати, интерпретирати и евалуирати статистичке показатеље, те формулисати смернице за педагошку дијагностику у сврху евалуације васпитно-образовне праксе; Издвојити, анализирати, презентовати критеријуме поделе и основне карактеристике појединих сегмената формал-

\footnotetext{
${ }^{3}$ Studijski program pedagogije, Filozofskog fakulteta u Nišu, preuzeto dana 17. 6. 2019. godine sa sajta: https://www.filfak.ni.ac.rs/studije/osnovne/pedagogija
} 
ног система васпитања и образовања (предшколски, школски, високошколски); Размењивати информације, идеје, проблеме и решења у професионалном контексту; Издвојити, анализирати и систематизовати темељне карактеристике и посебности појединих нивоа формалног, неформалног и информалног образовања и друго (Studijski program preddiplomskih, diplomskih i poslediplomskih studija pedagogije na Filozofskom fakultetu Sveučilištva u Zagrebu) ${ }^{4}$.

Као сличан исход студија педагогије на Филозофском факултету у Нишу и Филозофског факултета у Загребу и тиче се изучавања методолошких предмета, представља стицање компетенција познавања врста, метода и техника педагошких истраживања и предвиђања могућности и учинковитости њихове примене у васпитно-образовној пракси.

Систем високошколског образовања у Осијеку је сличан као на Филозофском факултету у Загребу. Овде се може додати информација да завршетком преддипломског нивоа студија (180 ЕЦТС) се стиче академски назив првоступник/ца друштвених наука - смер педагогија, затим завршетком дипломских студија (300 ЕЦТС) се стиче назив Магистар педагогије - наставнички смер и Магистар педагогије- општи/истраживачки смер (Studijski program pedagogije Filozofskog fakulteta u Osijeku) ${ }^{5}$. Основи задатак или исход предипломских студија јесте да се студенти оспособе и стекну аналитичке и социјалне вештине које ће их даље оспособити за дипломске студије педагогије и друге сродне науке.

За разлику од Филозофског факултета у Нишу, Филозофски факултет Свеучилишта у Ријеци студентима нуди далеко шири дијапазон педагошких дисциплина за изучавање које се могу сврстати у категорију обавезних или изборних (опште-образовних) предмета, и што такође детерминише и разлике у исходима учења ова два факултета. Аналогно Загребу и Осијеку, на Филозофском факултету у Ријеци студијски програм на овом нивоу студија укључује бројне предмете који студента припремају за непосредан практичан педагошки рад, а који нису заступљени на студијском програму педагогије Филозофског факултета у Нишу.

Као исходе студија педагогије Филозофског факултета свеучилишта у Ријеци могу се издвојити следећи циљеви и исходи образовања: Описати и расправљати о различитим теоријским концептима васпитно-образовних феномена у институционалним и ванинституционалним контекстима; Идентификовати и анализирати темељне теоријске одреднице планирања и програмирања васпитно-образовне делатности; Идентификовати и разликовати различите облике образовања и рада са циљним групама; Осмислити различите облике формалног и неформалног образовања и рада с циљним групама; Креирати

\footnotetext{
${ }^{4}$ Studijski program preddiplomskih, diplomskih i poslediplomskih studija pedagogije na Filozofskom fakultetu Sveučilištva u Zagrebu, preuzeto dana 16. 6. 2019. godine sa sajta: https://web2020.ffzg. unizg.hr/\#

${ }^{5}$ Studijski program pedagogije Filozofskog fakulteta u Osjeku, preuzeto dana 16. 6. 2019. godine sa sajta: https://www.ffos.unios.hr/
} 
план јавно-културне делатности васпитно-образовне институције; Идентификовати, објаснити и израдити различите врсте курикулума применом методологије израде курикулума из различитих теоријских приступа; Планирати и програмирати пројектне активности; Организовати и реализовати различите облике васпитно-образовног рада са циљним групама; Идентификовати, описати и анализирати различите административне послове педагога/андрагога; Идентификовати, описати, анализирати и користити педагошку/андрагошку документацију; Организовати, водити пројекте из различитих васпитно-образовних делатности (Studijski program pedagogije Filozofskog fakulteta u Rijeci) ${ }^{6}$.

Слично овом истраживању, изградњи професионалног идентитета и компарацијом силабуса бавиле су се ауторке Спасеновић и Хебиб (2014). Ауторке костатују да оно што је заједничко свим студијским програмима педагогије на овим просторима јесте да имају академски карактер, што значи да не припремају студенте само за непосредно деловање у пракси, већ пружају шире опште и теоријско образовање из области педагошке науке и сродних друштвено-хуманистичких научних дисциплина. Анализом студијских програма педагогије запажамо да се нагласак ставља на развој професионалне компетентности, тј. на развој општих и специфичних компетенција које су предуслов за успешно ангажовање у пракси образовног рада, али и за увођење у стручну и научну област педагогије. У неким земљама карактеристично је да се током основних студија педагогије ради на развоју већег броја компетенција које су претпоставка учешћа, односно остваривања помоћне улоге у реализацији стручних послова, а не самосталног обављања стручних послова педагога, како се експлицитно наглашава у студијским програмима педагогије који се реализују у Хрватској (Spasenović i Hebib, 2014: 4-5).

\section{2. Компаративна анализа методолошких предмета}

Компаративни метод као научни метод подразумева да су подаци који се представљају проверљиви на основу посматраних и уочених података, да је могуће урадити поновна иста или слична истраживања и вршити компарације, да су представљени објективни подаци, да су исти транспарентни и логички доследни.

Представљена тематика је била недвосмислено предмет за компаративно истраживање. Зашто методологија и анализа методолошке групе предмета? Модел изграђивања методолошке образованости требало би да се заснива на активном стицању истраживачке праксе током студирања, учењу на основу искуства, учењу о методолошким радионицама. При томе, испољава се заинтересованост за истраживачки рад и учење и формира методолошка оријентација као компонента методолошке компетенције.

\footnotetext{
${ }^{6}$ Studijski program pedagogije Filozofskog fakulteta u Rijeci, preuzeto dana, 16.6.2019. godine sa sajta: https://www.ffri.uniri.hr/hr/
} 
На основу компаративне анализе силабуса свих предмета који се изучавају на Филозофском факултету у Нишу и Филозофских факултета Свеучилишта у Загребу, Осијеку и Ријеци, конструисана је табела која показује заступљеност и вредновање методолошких предмета на основним академским студијама педагогије, а у другом случају предипломским студијама педагогије.

\section{Табела 1: Компарација методолошких предмета}

\begin{tabular}{|c|c|c|c|}
\hline $\begin{array}{c}\text { Филозофски факултет } \\
\text { у Нишу }\end{array}$ & $\begin{array}{c}\text { Филозофски факултет у } \\
\text { Загребу }\end{array}$ & $\begin{array}{c}\text { Филозофски факултет } \\
\text { у Осјеку }\end{array}$ & $\begin{array}{c}\text { Филозофски } \\
\text { факултет у Ријеци }\end{array}$ \\
\hline $\begin{array}{c}\text { Назив предмета } \\
\text { Предавања-Вежбе } \\
\text { ЕСПБ }\end{array}$ & $\begin{array}{c}\text { Назив предмета } \\
\text { Предавања-Вежбе } \\
\text { ЕСПБ }\end{array}$ & $\begin{array}{c}\text { Назив предмета } \\
\text { Предавања-Вежбе } \\
\text { ЕСПБ }\end{array}$ & $\begin{array}{c}\text { Назив предмета } \\
\text { Предавања-Вежсбе } \\
\text { ЕСПБ }\end{array}$ \\
\hline $\begin{array}{c}\text { Методологија педагогије } \\
2+2 \\
5 \text { ЕСПБ }\end{array}$ & $\begin{array}{c}\text { Увод у педагогијска } \\
\text { истраживања } \\
2+2 \\
5 \text { ЕСПБ }\end{array}$ & $\begin{array}{c}\text { Статистика у } \\
\text { педагошким } \\
\text { истраживањима } \\
2+1 \\
3 \text { ЕСПБ } \\
\end{array}$ & $\begin{array}{c}\text { Методологија } \\
\text { педагошких } \\
\text { истраживања } \\
2+3 \\
5 \text { ЕСПБ } \\
\end{array}$ \\
\hline $\begin{array}{c}\text { Статистика у } \\
\text { педагошким } \\
\text { истраживањима } \\
2+2 \\
5 \text { ЕСПБ }\end{array}$ & $\begin{array}{c}\text { Квалитативна } \\
\text { истраживања } \\
2+2 \\
5 \text { ЕСПБ }\end{array}$ & $\begin{array}{c}\text { Методологија } \\
\text { педагошких } \\
\text { истраживања } 1 \\
2+2 \\
5 \text { ЕСПБ }\end{array}$ & $\begin{array}{c}\text { Статистика у } \\
\text { педагошкој пракси и } \\
\text { истраживању } \\
2+3 \\
5 \text { ЕСПБ }\end{array}$ \\
\hline \multirow[t]{3}{*}{$\begin{array}{c}\text { Истраживања у } \\
\text { педагогији } \\
2+2 \\
5 \text { ЕСПБ }\end{array}$} & $\begin{array}{c}\text { Квантитативна } \\
\text { истраживања } \\
2+2 \\
5 \text { ЕСПБ }\end{array}$ & $\begin{array}{c}\text { Методологија } \\
\text { педагошких } \\
\text { истраживања } 2 \\
2+2 \\
5 \text { ЕСПБ } \\
\end{array}$ & \\
\hline & $\begin{array}{c}\text { Статистика у педагошким } \\
\text { истраживањима } \\
2+2 \\
5 \text { ЕСПБ }\end{array}$ & & \\
\hline & $\begin{array}{c}\text { Истраживачки } \\
\text { инструменти и евалуација } \\
2+2 \\
5 \text { ЕСПБ }\end{array}$ & & \\
\hline
\end{tabular}

Филозофски факултети у Хрватској на одељењима, односно одсецима за педагогију силабусима предвиђају изучавања методолошких предмета од прве године преддипломских студија. Највећи број методолошких предмета изучава се на Филозофском факултету у Загребу. Мале дистинкције се могу наћи у броју кредита по предмету у односу на Филозофски факултет у Осијеку и Ријеци. Методологија и статистика су нераскидиви предмети који се статусом обавезних предмета изучавају на сва четири факултета. Оно што смо уочили компарацијом силабуса јесу и слични начини евалуације (писмено и усмено).

На Филозофском факултету у Нишу на Департману за педагогију, студенти Статистику у педагошким истраживањима изучавају на конкретним примерима и егземпларима. У том смислу, сваки студент на рачунару подучава 
се начинима уноса, обраде и интерпретације података у SPSS програму. Статистичка база даје широк спектар статистичких процедура за основне анализе: Crosstabs, Chi Scuare, дескриптивну статистику, анализу варијансе, регресиону анализу, мултиваријантну статистику.

SPSS програм је све популарнији. Обука за коришћење програма је врло ефикасна, јер пакет за обраду података садржи широк спектар функција којима се студенти врло лако могу обучити. Притом програм олакшава студентима обраду, анализу и интерпретацију резултата истраживања, даје детаљне податке и изузетну визуелну подршку. Са друге стране, у садржајима методолошких предмета у Хрватској, не уочавају се слични начини реализације курсева, већ је наглашено да се практичн део реализује путем семинара и радионица без спецификације средстава и техничке, односно мултимедијалне подршке у раду са студентима на овом предмету.

Када се компаративном анализом сагледају циљеви, превасходно исходи студијских програма, а у њима конкретно методолошких предмета који су били предмет проучавања, можемо закључити да студенти педагогије стицањем знања из групе методолошких предмета требају бити оспособљени да:

1. Описују, класификују и упоређују различите методе истраживања, да разликују истраживачке парадигме, врсте истраживања, технике прикупљања и обраде података;

2. Истражују релевантну методолошку литературу за потребе истраживања;

3. Планирају и организују споровођење истраживања у контексту израде нацрта, прикупљања, обраде и анализе добијених података;

4. Критички процењују квалитет истраживања и врше компарацију са другим или сличним истраживањима.

Схватање педагога као истраживача претпоставља промену улоге педагога од корисника научних истраживања васпитно-образовне праксе у покретача истраживања у пракси. Истраживања у пракси се одређују као намерна, систематска, рефлексивна преиспитивања у контексту свакодневне праксе са циљем бољег разумевања и промене праксе. Методологија педагошких истраживања у пракси подстиче моћ и право практичара да истражује праксу и да на основу истраживања преузима одговорност за промену праксе (Krnjaja, 2014), због чега наши студијски програми теже да будуће педагоге кроз студије педагогије оформе у практичаре и истраживаче.

\section{Закључак}

Иницијално образовање педагога, како у Србији, тако и земљама у региону, доживело је последњих година значајне промене под утицајем Болоњског процеса, односно ширих реформи у области високог образовања (VujisićŽivković, 2009). Образовање и оспособљавање студената педагогије за професионални рад у нашим условима постиже се кроз теоријска предавања, вежбе, консултативни рад, стручну педагошко-методичку праксу, „,радом на терену“. 
Тежили смо да компарацијом силабуса Филозофског факултета у Нишу и Филозофских факултета Свеучилшта у Загребу, Осијеку и Ријеци лоцирамо статус методолошких предмета у систему универзитетског образовања. Уочено је да су методолошки предмети релативно добро заступљени кроз студије педагогије, а највише на Филозофском факултету Свеучилишта у Загребу који подразумева низ обавезних методолошких предмета на студијама.

Овај компаративни рад има за апликативни циљ да укаже на значај методолошког образовања будућих педагога за будуће професионално деловање. Овим потврђујемо схватања чувених методолога Шона (Schön, 1990), МекНифa (McNiff, 2002), Фулана (Fullan, 1993), па и наших домаћих аутора Банђура и Поткоњака (1999), Мужића (2004), Халмија (2004) и бројних других. Сви они говоре о значају познавања методолошких парадигми. Студенти преузимајући активну улогу постају рефлексивни практичари и истраживачи. Истраживачка пракса и методолошка оспособљеност студената педагогије подразумевају не само теоријска методолошка знања, већ сасвим конкретна знања и компетенције које су неопходне за избор адекватних методолошких поступака, анализу и интерпретацију сређених и обрађених података, као и презентовање резултата истраживања. Анализом студијских програма препознат је значај познавања методологије. Изучавањем методолошких предмета студенти, будући педагози, развијају вештине, способности, интересовања и инстраживачке компетенције које су преко потребне за рад у васпитно-образовној пракси.

\section{Литература}

Banđur, V. i Potkonjak, N. (1999). Metodologija pedagogije. Beograd: Savez pedagoških društava Jugoslavije.

Bodroški Spariosu, B. (2015), Univerzitetsko obrazovanje - od Humboltovog modela do Bolonjskog procesa, Nastava i vaspitanje, LXIV, 3, 407-420.

Cohen, L., Manion, L., Morrison, K. (2007). Metode istraživanja u obrazovanju (5. izdanje). Zagreb: Naklada Slap.

Fullan, M. (1993). Change forces: Probing the depths of educational reform. London: Falmer.

Halmi, A. (2004). Strategije kvalitativnih istraživanja u primijenjenim društvenim znanostima. Jastrebarsko: Naklada Slap

Kopas-Vukašinović, E. i Maksimović, J. (2010). Interesovanja studenata pedagogije za profesionalno angažovanje i istraživački rad. Nastava $i$ vaspitanje, 59(4), 587-602.

Milas, G. (2005). Istraživačke metode u psihologiji i drugim društvenim znanostima. Zagreb: Naklada Slap.

Krnjaja, Ž. (2014). Pedagog kao istraživač. Naučni skup: Januarski susreti pedagoga „Identitet profesije pedagog u savremenom obrazovanju“, 8-14. Beograd: Filozofski fakultet.

McNiff, J. (2002). Action research for professional development. Online: http://www. 
jeanmcniff.com/booklet1.html (10.12.2012)

Mužić, V. (2004). Uvod u metodologiju istraživanja odgoja i obrazovanja. Zagreb: EDUCA

Schön, D. (1990). Educating the Reflective Practitioner: Toward a New Design for Teaching and Learning in the Professions. San Francisco/Oxford: Jossey-Bass Publishers.

Savićević, D.M. (1996). Metodologija istraživanja u vaspitanju i obrazovanju. Vranje: Učiteljski fakultet

Spasenović, V. i Hebib, E. (2014). Kako inicijalno obrazovanje i zahtevi prakse doprinose izgradnji profesionalnog identiteta pedagoga. Naučni skup: Januarski susreti pedagoga „Identitet profesije pedagog u savremenom obrazovanju“, 2-7. Beograd: Filozofski fakultet

Studijski program pedagogije, Filozofskog fakulteta u Nišu, preuzeto dana 17. 6. 2019. godine sa sajta: https://www.filfak.ni.ac.rs/studije/osnovne/pedagogija

Studijski program preddiplomskih, diplomskih i poslediplomskih studija pedagogije na Filozofskom fakultetu Sveučilištva u Zagrebu, preuzeto dana 16. 6. 2019. godine sa sajta: https://web2020.ffzg.unizg.hr/\#

Studijski program pedagogije Filozofskog fakulteta u Osjeku, preuzeto dana 16. 6. 2019. godine sa sajta: https://www.ffos.unios.hr/

Studijski program pedagogije Filozofskog fakulteta u Rijeci, preuzeto dana, 16. 6. 2019. godine sa sajta: https://www.ffri.uniri.hr/hr/

Vujisić Živković, N. (2009). Proces disciplinarizacije u polju pedagoškog istraživanja i obrazovanja - drugi deo: savremeni razvoj pedagogije kao univerzitetske discipline. Pedagogija, 64, 1, 42-59.

\title{
COMPARATIVE ANALYSIS OF THE METHODOLOGICAL GROUP OF SUBJECTS ON STUDY PROGRAMS OF PEDAGOGY IN NIŠ, ZAGREB, OSIJEK AND RIJEKA
}

\author{
Jelena Maksimović, Jelena Osmanović \\ University of Nis, Faculty of Philosophy, Department of Pedagogy
}

\begin{abstract}
The aim of the basic studies of pedagogy is to achieve competencies, skills and skills for work in educational and educational activities. Students of pedagogy are expected to constantly evaluate and innovate the educational process with the help of adequate methods, techniques and instruments in the future workplace. The subject of research is a comparison of the presence of methodological subjects at the Faculty of Philosophy in Niš, Zagreb, Osijek and Rijeka. The tasks of comparative research are: 1 . To analyze the syllabuses of the study program of pedagogy; 2. By comparing it, determine the similarities and differences in the study of the methodological group
\end{abstract}


of subjects of study programs of pedagogy at the aforementioned four faculties. The results of the comparative research show that methodological subjects are represented through pedagogy studies and the largest number of subjects are represented at the Faculty of Philosophy of the University of Zagreb. It is concluded that the study programs are striving to provide future pedagogues through pedagogy education to practitioners and researchers.

Key words: comparative method, methodological subjects, study programs, silabuses

\section{Citiranje članka:}

Maksimović, J. i Osmanović, J. (2019). Komparativna analiza metodološke grupe predmeta na studijskim programima pedagogije filozofskog fakulteta u Nišu, Zagrebu, Osijeku i Rijeci. Godišnjak za pedagogiju, 4(1), 61-70 